\title{
Endoscopic Endonasal versus Microscopic Trans-Sphenoidal Surgery for Recurrent Pituitary Adenomas: Comparative Study
}

\author{
MOHAMED KESHK, M.D. \\ The Department of Neuro-Surgery, Al-Azhar University, Cairo, Egypt
}

\begin{abstract}
Background: Pituitary adenoma is a common brain tumor It accounts for $10-25 \%$ of all intracranial tumors.

Treatment of recurrent pituitary adenomas is often surgically either endoscopic or microscopic with the advantages of endoscopic approach due to visualization of residual tumor and limited field of view of the microscope.
\end{abstract}

Aim of Study: The aim of this study was to compare the efficacy and results of endoscopic and microscopic transsphenoidal surgery of recurrent pituitary adenoma.

Patients and Methods: This is prospective study was carried out on 34 patients of recurrent pituitary adenomas at Neurosurgery Departments, Al-Azhar University Hospitals and Mohammed Dossary Hospital Al-Khobar, KSA.

Adult patients who had tumor recurrence or residual tumor underwent revision surgery. While those underwent radiotherapy/radio surgery or receiving medical therapy for remission were excluded.

Patients were classified into group A subjected to endoscopic removal and group B subjected to microscopic resection of the recurrent pituitary adenoma.

All patients in the study were subjected to clinical, imaging and laboratory studies for the diagnosis and extent of the tumor.

Results: Our results revealed no difference between both groups regarding gender of age ( $p=0.412$ and 0.631 respectively); presenting symptoms ( $p=0.413)$. Operative time was significantly longer in group $\mathrm{B}(p=0.01)$ and intraoperative blood loss was much in group $\mathrm{B}(p=0.02)$.

Endoscopic removal of macro adenomas is significantly more than microscopic approach $(p=0.032)$ also, complete excision of tumor in endoscopic approach is significantly more than microscopic approach (0.035). Also, the readmission rate and late complications were more in group B than groups A but without difference ( $p=0.241$ and 0.351 respectively) also, there was no difference between groups regarding total hospital stay $(p=0.601)$.

Conclusion: Reoperation for recurrent or residual pituitary adenomas is a safe and effective treatment option. Endoscopic

Correspondence to: Dr. Mohamed Keshk, The Department of Neuro-Surgery, Al-Azhar University, Cairo, Egypt approach more effective than microscopic approach due to wide orientation, more resection, less operative and postoperative complications with shorter hospital stay.

Key Words: PA, Pituitary adenomas - GTR, Gross total resection - $R T$, Radiotherapy.

\section{Introduction}

PITUITARY adenoma (PA) is a common primary brain tumor with benign features, and surgical resection continues to be the preferred treatment with the exception of prolactin-secreting tumors [1].

PAs account for $10-25 \%$ of all intracranial tumors and are relatively common. Clinically, PAs are classified into nonfunctioning and functioning. They are divided into groups based on size, which include micro adenomas $(<1 \mathrm{~cm})$, macro adenomas $(\geq 1 \mathrm{~cm}$ and $<4 \mathrm{~cm})$, and giant adenomas $(>4 \mathrm{~cm})$ $[2,3]$.

Recurrent tumors can be managed with observation, medical therapy, radiotherapy, radiosurgery, or revision surgery [1].

Treatment of pituitary adenomas is often surgical, especially in hormone secreting tumors or those with a mass effect on surrounding structures, such as the optic chiasm $[4,5]$.

Pituitary tumors surgery still represents a significant challenge, despite the highly refined nature of the contemporary microsurgery. Over the past decade, the evolution of pituitary tumors surgery had been characterized by progressive trends toward less invasive approach. The endonasal endoscopic approach provides less invasive approach to the pituitary gland and surrounding area, in addition to providing betters intraoperative imaging of the region $[3,6]$ 
Surgery for a recurrent or residual lesion is burdened by an increased risk of morbidity and mortality and more often results in incomplete resection compared with the primary surgery. Repeat transsphenoidal surgery is generally more difficult to perform than the initial operation $[\mathbf{7 , 8 , 9 ]}$

Transsphenoidal resection of a pituitary adenoma is one of the most commonly performed surgeries for intracranial tumors. Although the rate of gross total resection is high for small tumors, residual tumor following resection is not uncommon, particularly for larger tumors, where gross total resection (GTR) rates can be as low as 25$40 \%$ [9].

The nature of the pituitary adenoma itself suggests the possibility of tumor recurrence, regardless of its endocrinological characteristics. Recurrence rate of pituitary adenoma after surgical resection has been reported up to $30 \%$, and regrowth after incomplete tumor removal was reported in up to $75 \%$ of cases $[\mathbf{1 , 1 0 ]}$

The application of endoscopy to pituitary surgery is based on multiple theoretical advantages including improved visualization, preservation of sinonasal function, reduced hospital length of stay, increased patient comfort, and reduced complications [9].

The endoscopic approach would offer advantages such as the ability to visualize areas of residual tumor that might not be visible with the more limited field of view of the microscope. However, the frequent scarring tissue and more fibrotic surgical environment in redo surgeries can be challenging with the absence of direct stereoscopic visualization as proved by the microscope. The more challenging bimanual dissection through the endoscope, and the difficulty of skull base reconstruction in redo surgery might also limit the benefits or increase the complications of endoscopic approaches. Evaluation of the outcome and safety of these 2 approaches in recurrent/residual cases is even more pertinent in the light of the relative recent development of complementary adjuvant treatments such as radiosurgery [11,12].

\section{Patients and Methods}

This is prospective comparative study was carried out on 34 patients of recurrent pituitary adenomas at Neurosurgery Departments Al-Azhar University Hospitals and Mohammed Dossary Hospital Al-Khobar KSA. In the period between April 2015 till April 2019.
After approval of local ethics committee, all patients included in the study or their relatives were informed well about the procedure and had an informed written consent before carrying the procedure.

All patients in the study were subjected to: (A) Clinical assessment in the form of complete history taking, clinical examination to confirm the visual field and to exclude invasion. (B) Laboratory investigations in the form of hormonal profile complete blood picture, coagulation profile, liver function tests, kidney function tests and blood chemistry: include blood glucose level. (C) Imaging studies: included (1) Brain CT and (2) Brain MRI examination to confirm the diagnosis and exclude invasion. Ophthalmologist consultation: for visual field assessment using perimetry.

\section{Patients have been classified into two groups:}

Group A: Include 18 patients who underwent endoscopic surgery of recurrent adenomas or residual tumor not completely removed during the first surgical procedure. Of these, 11 had previously undergone surgery via a micro surgical transsphenoidal approach, 7 by means of an endoscopic trans sphenoidal route. This group had 9 non secreting adenomas, $5 \mathrm{GH}$ secreting adenomas, 3 PRL secreting adenoma, and 1 ACTH secreting adenoma. Of these, 17 were macro adenomas, while 1 was a micro adenoma.

Group B: Included 16 patients who underwent microscopic surgery of recurrent adenomas or residual tumor not completely removed during the first surgical procedure. Of these, 12 had previously undergone surgery via a micro surgical trans sphenoidal approach, 4 by means of an endoscopic trans sphenoidal route This group had 10 non secreting adenomas, $4 \mathrm{GH}$ secreting adenomas, 2 PRL secreting adenoma, of these, 10 were macro adenomas, while 6 was a micro adenoma.

\section{Inclusion criteria:}

Adult patients, of both genders, with pituitary adenoma, who experienced tumor recurrence or residual tumor after primary surgery and underwent revision surgery were included in the study.

\section{Exclusion criteria:}

We excluded patients who either underwent radiotherapy (RT)/radio surgery or who were receiving medical therapy to attain remission previously to the second trans sphenoidal surgery. 


\section{Operative technique:}

Operative endoscopic endonasal trans-sphenoid trans-sellar approach was carried out as described by Hwang et al., [1] .

The procedures were performed using, endoscopic endonasal trans-sphenoid trans-sellar approach. The extent of sphenoidotomy was made to visualize the tuberculum and clival recess. The wide panoramic view of endoscope had a critical role to identify the skullbase bony structures. After sphenoidotomy, we always identified the bilateral optic canals and clival ICA protuberances before removing scar tissue on sella, because the scar tissue often precluded the identification of the bilateral cavernous ICA protuberances. The dissection of fibrous tissues on the sella started at the imaginary midline from the midpoint bilateral optic canals to the midline of clival recess and continued to expose the medial margin of cavernous sinus. The autologous or artificial reconstructive materials used in previous surgery adhered to the dura. Therefore, we drilled circumferentially the margin of previous sellar opening in order to visualize the adhesion site between dura and reconstructive materials and avoid the unintended dural damage. The dissection of reconstruction materials was performed gently and then the wide sellar bony window was created. After a creating dural opening, we attempted to perform extracapsular dissection circumferentially. Internal decompression with piecemeal fashion was performed in cases without a prominent pseudo capsule. We tried to remove the intracavernous tumor through the defect of cavernous Wall made by the tumor from medial to lateral side. The direct approach to the lateral component of cavernous sinus was performed only when the tumor completely surrounded the anterior surface of the ICA siphon portion. The tumor in the cavernous sinus was removed under direct view of angled endoscope ( 30 or 45 degree) in all cases and blind curettage was never used. The tumors adhering severely to the ICA or pituitary gland were not removed and the blind curettage was not used in order to avoid dangerous conditions. No special reconstruction technique of skull base defect was required in of any patients, however, we combined various techniques such as multi-layers of collagen fleece coated with fibrin sealant, on-lay graft of injectable hydroxyapatite if intraoperative cerebrospinal fluid (CSF) leakage.

\section{Microscopic surgery:}

Was similar to endoscopic surgery, except that it requires Hardy's speculum and was done under visualization with a microscope instead of endoscope.

Follow-up of patients is by clinical observation of post-operative pain, affection of the visual field, neurological assessment "convulsion or any other affection", CT and MRI of the brain to detect efficiency of the procedure and recurrence of the tumor for three months.

Complications during operative procedure and during the period of follow-up were detected and recorded.

Data were analyzed using IBM SPSS software package version 20.0 (Belmont, Calf, 2013). Data were collected in tables then analyzed in regarding to Chi square $\left(\chi^{2}\right)$ and $p$-value less than 0.05 were considered significant.

\section{Results}

In groups A, 11 were females $(61.1 \%)$ and 7 (38.9\%) were males with a male to female ratio of 1: 1.6. The mean age of the patients in endoscopic group was $46.3 \pm 10.45$ years (ranged $30-67$ years), and in microscopic group (group B), there were 9 $(56.25 \%)$ males and $7(43.75 \%)$ females with a male to female ratio of 1.3:1 and the mean age was $42.5 \pm 12.1$ years (ranged 18-61 years). The statistical analysis revealed that there was no significant difference between both groups regarding gender $(p=0.412)$ or age $(p=0.631)$.

The most common presenting symptom was a headache (group A 83.3\%; group B 87.5\%) and second most common symptom was disturbances of vision (66.6\% in group A and $75 \%$ in group B) and the statistical analysis revealed that there was no significant difference between both groups regarding the presenting symptoms $(p=0.231$ and 0.320 respectively). The mean duration of symptoms in endoscopic group was $28.1 \pm 12.3$ months (ranged from 2-72 months), and in microscopic group, it was $22.4 \pm 16.1$ months (ranged from 160 month). The statistical analysis revealed that there was no significant difference between both groups regarding the duration of the presenting symptoms $(p=0.413)$.

The operative time in group A ranged between $90-155$ with a mean operative time of $120 \pm 2.3 \mathrm{~min}$ while in group $\mathrm{B}$ the operative time ranged between 130-190min with a mean operative time of $175 \pm 5.1 \mathrm{~min}$ and the statistical analysis revealed that the operative time was significantly longer in group $\mathrm{B}(p=0.01)$ (Table 1, Fig. 1). 
Table (1): Perioperative data of patients of both groups of the study.

\begin{tabular}{|c|c|c|c|}
\hline Variable & $\begin{array}{c}\text { Group A } \\
n=18\end{array}$ & $\begin{array}{c}\text { Group B } \\
n=16\end{array}$ & $p$ \\
\hline \multicolumn{4}{|l|}{ Age (years): } \\
\hline Range & $30-67$ & $18-61$ & \multirow[t]{2}{*}{$0.631(\mathrm{NS})$} \\
\hline Mean \pm S.D & $46.3 \pm 10.45$ & $42.5 \pm 12.1$ & \\
\hline \multicolumn{4}{|l|}{ Sex: } \\
\hline Male & $7(38.9 \%)$ & $9(56.3 \%)$ & \multirow[t]{2}{*}{0.412 (NS) } \\
\hline Female & $11(61.1 \%)$ & $7(43.7 \%)$ & \\
\hline \multicolumn{4}{|l|}{ Presenting symptoms: } \\
\hline Headache & $15(83.3 \%)$ & $14(87.5 \%)$ & $0.231(\mathrm{NS})$ \\
\hline Visual disturbances & $12(66.7 \%)$ & $12(75 \%)$ & $0.320(\mathrm{NS})$ \\
\hline \multicolumn{4}{|l|}{$\begin{array}{l}\text { Duration of symptoms } \\
\text { (Months): }\end{array}$} \\
\hline Range & $2-72$ & $1-60$ & \multirow[t]{2}{*}{0.431 (NS) } \\
\hline Mean \pm S.D & $28.1 \pm 12.3$ & $22.4 \pm 16.1$ & \\
\hline \multicolumn{4}{|l|}{ Operative time (Min): } \\
\hline Range & $90-155$ & $130-190$ & \multirow[t]{2}{*}{$0.01(\mathrm{~S})$} \\
\hline Mean \pm S.D & $120 \pm 2.3$ & $175 \pm 5.1$ & \\
\hline \multicolumn{4}{|l|}{$\begin{array}{l}\text { Intraoperative blood } \\
\text { loss }(\mathrm{ml}) \text { : }\end{array}$} \\
\hline Range & $100-230$ & $130-300$ & \multirow[t]{2}{*}{$0.02(\mathrm{~S})$} \\
\hline Mean \pm S.D & $150 \pm 30$ & $200 \pm 45$ & \\
\hline \multirow{2}{*}{\multicolumn{4}{|c|}{$\begin{array}{l}\text { Extent of tumor } \\
\text { excision: }\end{array}$}} \\
\hline $\begin{array}{l}\text { excision: } \\
\quad \text { Complete excision }\end{array}$ & $11(61.1 \%)$ & & \\
\hline Partial excision & $7(38.9 \%)$ & $9(56.25 \%)$ & $0.035(\mathrm{~S})$ \\
\hline \multicolumn{4}{|l|}{ (readmission): } \\
\hline Hematoma & $1(5.55 \%)$ & $1(6.25 \%)$ & \multirow[t]{2}{*}{$0.241(\mathrm{NS})$} \\
\hline CFS leakage & $1(5.55 \%)$ & $2(12.5 \%)$ & \\
\hline \multicolumn{4}{|l|}{ complications: } \\
\hline Diabetes insipidus & $4(22.2 \%)$ & $5(31.25 \%)$ & \multirow[t]{2}{*}{$0.351(\mathrm{NS})$} \\
\hline Sinusitis & $2(11.1 \%)$ & $3(18.75 \%)$ & \\
\hline \multicolumn{4}{|l|}{$\begin{array}{l}\text { Total hospital stay } \\
\text { (days): }\end{array}$} \\
\hline Range & $6-13$ & $7-16$ & \multirow[t]{2}{*}{$0.601(\mathrm{NS})$} \\
\hline Mean \pm S.D & $10 \pm 2.4$ & $11.5 \pm 3.1$ & \\
\hline
\end{tabular}

Intraoperative blood loss in group A ranged between $100-230 \mathrm{ml}$ with a mean blood loss of $150 \pm 30 \mathrm{ml}$ while in group B the intraoperative blood loss ranged between $130-300 \mathrm{ml}$ with a mean blood loss of $200 \pm 45 \mathrm{ml}$ and the statistical analysis revealed significant intraoperative blood loss in group $\mathrm{B}$ than in group $\mathrm{A}(p=0.02)$ (Table 1, Fig. 1).

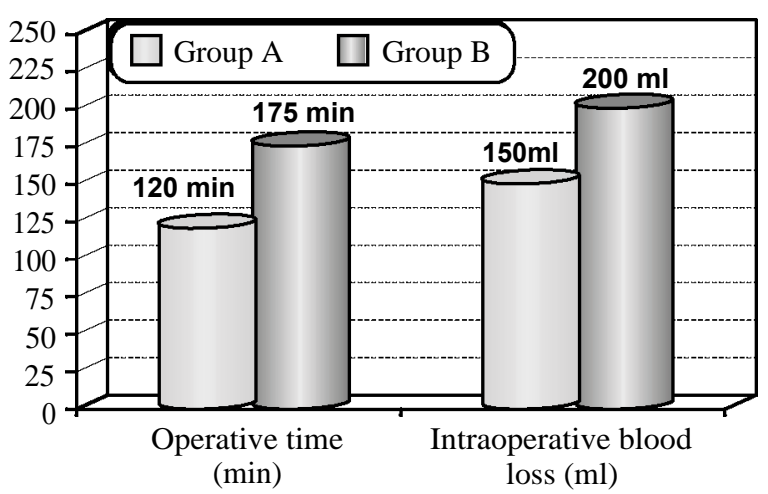

Fig. (1): Operative data of patients of the study.
According to tumor size in group A 17 (94.44\%) and $1(5.55 \%)$ macro- and micro-adenoma respectively while in group B $10(62.5 \%)$ and $6(37.5 \%)$ macro- and micro-adenoma respectively and the statistical analysis signify the difference between both groups regarding tumor size ( $p=0.032)$ also, in each group the removal of macro-adenomas were much better than microadenomas $(p=0.001$ and 0.031 respectively), (Table 2 ).

Table (2): Tumor size in relation to the procedure of removal of patients of both groups of the study.

\begin{tabular}{lcccccc}
\hline \multirow{2}{*}{ Tumor size } & \multicolumn{2}{c}{$\begin{array}{c}\text { Group A } \\
\mathrm{n}=18\end{array}$} & \multicolumn{2}{c}{$\begin{array}{c}\text { Group B } \\
\mathrm{n}=16\end{array}$} & \multirow{2}{*}{$\boldsymbol{P}$} \\
\cline { 2 - 5 } & \multicolumn{2}{c}{ No. } & $\%$ & No. & $\%$ & \\
\hline Micro-adenoma & 1 & 5.6 & 6 & 37.5 & 0.021 \\
Macro-adenoma & 17 & 94.4 & 10 & 62.5 & 0.032 \\
$p$ & & 0.001 (HS) & \multicolumn{2}{c}{$0.031(\mathrm{~S})$} & \\
\hline
\end{tabular}

Tumor excision In group A complete tumor excision was achieved in $11(61.1 \%)$ patients and partial excision achieved in 7 (38.9\%) of patients while in group B complete excision was achieved in 7 patients (43.75) and partial excision was achieved in 9 patients $(56.25 \%)$ and the statistical analysis showed significant increase of complete excision in endoscope than microscopic excision regarding completeness of excision $(p=0.035)$.

Readmission in group A was performed in two patients $(11.1 \%)$ one was for evacuation of postoperative hematoma and the other was due to CSF leakage while in group B was performed in 3 cases $(118.75 \%)$ two of them for CSF leakage and the remaining one was performed for evacuation of post-operative hematoma and the statistical analysis revealed inspit of increase in the rate of readmission in group B but it didn't reach a significant difference from group A $(p=0.241)$. All the patients after surgery had improvement in a headache and vision in both groups.

Late post-operative complications in group A were lower than in group B but with no significant difference $(p=0.351)$ they were in the form of diabetes insipidus ( $22.2 \%$ vs $31.25 \%$ respectively), and sinusitis ( $11.1 \%$ vs $18.75 \%$ respectively).

The hospital stay in group A ranged between 6 - 13 c days with a mean of $10 \pm 2.4$ day while in group $\mathrm{B}$ the total hospital stay ranged between 7 16 days with a mean period of $11.5 \pm 3.1$ days and the statistical analysis revealed no difference between both groups regarding the total hospital stay $(p=0.601)$. 


\section{Discussion}

In our study there was no difference between groups regarding age, gender, presenting symptoms and/or its duration.

Esquinazi et al., (2017) reported in their study that in 8 meta-analysis studies, males were more common than females but without significance also, there was no significance difference between endoscopic and microscopic groups regarding age that run in line with our study (Esquenazi et al., 2017) [9].

Operative time was more prolonged in microscopic than endoscopic group of the study also, blood loss were more in microscopic group than endoscopic group of the study.

Prajapati et al., (2018) found in their study prolonged operative time in microscopic than endoscopic group also, blood loss was more in microscopic than endoscopic as in our study (Prajapati et al., 2018) [3].

Inspit of complete excision was more in endoscopic than in microscopic procedure with a significant difference towards endoscopic procedure. Gao et al., (2016), had showed greater percentage of gross total resection in endoscopic group in comparison to microscopic group which favor our study (Gao et al., 2016) [13].

Prajapati et al., (2018) found that complete excision was more commonly achieved in microscopic than endoscopic group and this was disagree with our study (Prajapati et al., 2018) [3].

Our experience in endoscopic gross total resection was advanced than Microsocpic surgery which are coping with Many studies [7,14,15,16].

The reports in the literatures on recurrent TSA Showed that endoscopic approach achieved at least comparable outcomes with microscopic approaches (Table 3) [1]

Table (3): Microscopic or endoscopic TSA for recurrent pituitary adenomas in literatures.

\begin{tabular}{llccl}
\hline $\begin{array}{l}\text { Type of } \\
\text { surgery }\end{array}$ & Authors & $\begin{array}{c}\text { No. of } \\
\text { cases }\end{array}$ & $\begin{array}{c}\text { Gross total } \\
\text { removal } \\
{[\mathrm{n}(\%)]}\end{array}$ & $\begin{array}{c}\text { Complications } \\
{[\mathrm{n}(\%)]}\end{array}$ \\
\hline Microscopic & Yamada et al. & 53 & $31(59)$ & $5(9)$ \\
& Benveniste et al. & 96 & NA & $29(31.3)^{*}$ \\
& Mattozo et al. & 30 & $17(57)$ & $5(17)$ \\
\multirow{2}{*}{ Endoscopic } & Cavallo et al. & 59 & $37(63)$ & $5(8)$ \\
& Rudnik et al. & 20 & $8(40)$ & $4(20)$ \\
& Hwang et al. & 30 & $15(50)$ & $5(16)$ \\
\hline
\end{tabular}

*Number of complications is overlapped. TSA: Trans-sphenoidal.
In contrast to these studies; Bodaghabadi et al., (2014), found in their study that gross total excision was achieved more in microscopic procedures than endoscopic procedures which disagree with our results Bodaghabadi et al., [4] .

Based on the statistical data of our study endoscopic surgery is recommended in recurrent macro adenoma cases regarding gross total resection, short operative time, less blood loss and short hospital stay.

Komotar RJ et al., [17] found that Improvements in visualization and extensive approaches possible through the endoscope result in improved outcomes for larger lesions when compared with classic microscopic surgery.

Complications were more common in endoscopic than in microscopic group "in the form of CSF leak, hematoma" but without significance but late complications "sinusitis and diabetes insipidus" was more common in microscopic than endoscopic group.

Complications in the group of Prajapati et al., [3] was found to be more in microscopic than endoscopic group as in our study [3]

Broesren et al., (2018) found the CSF leak was more common in endoscopic than microscopic surgery for pituitary ademonas and transient diabetes insipidus was more common in microscopic procedures which run in line with our results Broesren et al., [18].

The appropriate tumor exposure and precise resection in revision surgery more difficult and higher complications rates were reported, even when performed by experienced surgeons Yamada S, et al., [19]

Post-operative diabetes insipidus was less frequent in those having endoscopic surgery ( $28 \%$ versus $15 \%$ ). However, it has not been elucidated well whether the endoscopic TSA could provide a similar or better outcome than microscopic TSA for recurrent pituitary adenoma despite of theoretical benefits these results were as in our study Goudakos et al., [20] .

Jain et al., (2007) concluded in their study that in endoscopic surgery there were less postoperative complication less operative time as compared to endonasal transsphenoidal microscopic surgery but complete tumor excision was achieved in the same percentage of patients in both groups that run in line with our results Jain et al., [21]. 
Many studies as Cavalla et al., (2013); Paluzzi et al., (2014); Tajudeen et al., (2015) and Singh et al., (2016), found that complications in the form of CSF leakage, sellar hematoma were more common in endoscopic group than microscopic group which was in agree with our results (Cavallo et al., Paluzzi et al., Tajudeen et al., Singh et al., $[7,14,15,16]$.

There no difference between both groups regarding hospital stay. Also, Prajapati et al., (2018) found in their study a longer total hospital stay in microscopic than endoscopic group but without significance as in our study Prajapati et al., [3] .

Finally, Little et al., (2019), concluded in their study that Gross-total resection was achieved in $80.0 \%$ of microscopic surgery patients and $83.7 \%$ of endoscopic surgery patients. Volumetric extent of resection (GTR), length of stay, surgery-related deaths didn't differe between both groups while microscopic surgery cases were significantly shorter in duration than endoscopic surgery cases this run in line with our results Little et al., [22].

\section{Limitations:}

Number of cases and short term follow-up are the limitations of our study. We recommend further studies on large group of patients with long term follow-up.

\section{Conclusion:}

Surgery for recurrent or residual pituitary adenomas is a safe and effective. We recommend Endoscopic approach for all recurrent or residual adenomas notably macro adenoma as it provides a wide surgical field and broad vision of tumor tissues, leading to modest increases in resection rates, less blood loss, less operative time, less postoperative complication, and early discharge from the hospital.

\section{References}

1- HWANG J.M., KIM Y.H., KIM J.W., KIM D.G., JUNG H.W. and CHUNG Y.S.: Feasibility of Endoscopic Endonasal Approach for Recurrent Pituitary Adenomas after Microscopic Trans Sphenoidal Approach. J. Korean Neurosurgery Soc., 54: 317-322, 2013.

2- KIM J.S., LEE Y.S., JUNG M.J. and HONG Y.K.: The Predictive Value of Pathologic Features in Pituitary Adenoma and Correlation with Pituitary Adenoma Recurrence. J. Pathol. Transl. Med., 50: 419-425, 2016.

3- PRAJAPATI H.P., JAIN S.K. and SINHA V.D.: Endoscopic versus microscopic pituitary adenoma surgery: An institutional experience. Asian J. Neurosurg., 13: 217-21, 2018.

4- BODAGHABADI M., RIAZI H., ARAN S., BITARAF M.A., ALIKHANI M., ALAHVERDI M., et al.: Repeated transsphenoidal surgery or Gamma Knife radiosurgery in recurrent Cushing disease after transsphenoidal surgery. J. Neurol. Surg. A Cent. Eur. Neurosurg., 75: 91-97, 2014.

5- HERINGER L.C., de OLIVEIRA M.F., ROTTA J.M. and BOTELHO R.V.: Effect of repeated transsphenoidal surgery in recurrent or residual pituitary adenomas: A systematic review and meta-analysis. Surg. Neurol. Int., 7: 14-21, 2016.

6- ELTABL M.A., ELADAWY Y.M., HANAFY A.M., GABER SALEH E.E. and ELNOOMANY H.A.: Surgical outcome of endoscopic versus microscopic transsphenoidal approach for pituitary adenoma. Menoufia Med. J., 28: 87-92, 2015.

7- CAVALLO L.M., SOLARI D., TASIOU A., ESPOSITO F., de ANGELIS M. and D'ENZA A.I., et al.: Endoscopic endonasal transsphenoidal removal of recurrent and regrowing pituitary adenomas: experience on a 59-patient series. World Neurosurg., 80: 342-350, 2013.

8- LAWS E.R.: The endoscopic endonasal approach for recurrent pituitary lesions. World Neurosurg., 80: 272273,2013

9- ESQUENAZI Y., ESSAYED W.I., SINGH H., MAUER E., AHMED M., CHRISTOS P.J. and SCHWARTZ T.H.: Endoscopic Endonasal Versus Microscopic Transsphenoidal Surgery for Recurrent and/or Residual Pituitary Adenomas. World Neurosurg., 101: 186-195, 2017.

10- YILDIRIM A.E., DIVANLIOGLU D., NACAR O.A., et al.: Incidence, hormonal distribution and postoperative follow up of atypical pituitary adenomas. Turk Neurosurg., 23: 226-31, 2013.

11-DING D., STARKE R.M. and SHEEHAN J.P.: Treatment paradigms for pituitary adenomas: Defining the roles of radiosurgery and radiation therapy. J. Neurooncol., 117: 445-457, 2014.

12-LEE C.C. and SHEEHAN J.P.: Advances in Gamma Knife radiosurgery for pituitary tumors. Curr. Opin. Endocrinol. Diabetes Obes., 23: 331-338, 2016.

13- GAO Y., ZHENG H., XU S., ZHENG Y., WANG Y., JIANG J., et al.: Endoscopic versus microscopic approach in pituitary surgery. J. Craniofac. Surg., 27: e157-9, 2016.

14- PALUZZI A., FERNANDEZ-MIRANDA J.C., TONYA STEFKO S., CHALLINOR S., SNYDERMAN C.H. and Gardner P.A.: Endoscopic endonasal approach for pituitary adenomas: A series of 555 patients. Pituitary, 17: 307319,2014

15-TAJUDEEN B.A., MUNDI J., SUH J.D., BERGSNEIDER M. and WANG M.B.: Endoscopic endonasal surgery for recurrent pituitary tumors: Technical challenges to the surgical approach. J. Neurol. Surg B Skull Base, 76: 50$56,2015$.

16- SINGH H., ESSAYED W.I., COHEN-GADOL A., ZADA G. and SCHWARTZ T.H.: Resection of pituitary tumors: Endoscopic versus microscopic. J. Neuro-oncol., 130: 309-317, 2016.

17- KOMOTAR R.J., STARKE R.M., RAPER D.M., ANAND V.K. and SCHWARTZ T.H.: Endoscopic endonasal compared with microscopic transsphenoidal and open Trans cranial resection of giant pituitary adenomas. Pituitary, 15: 150-159, 2012. 
18- BROERSEN L.H.A., BIERMASZ N.R., VAN FURTH W.R., de VRIES F., VERSTEGEN M.J.T., DEKKERS O.M. and PEREIRA1 O.M.: Endoscopic vs. microscopic transsphenoidal surgery for Cushing's disease: A systematic review and meta-analysis. Pituitary available at: https://doi.org/10.1007/s11102-018-0893-3, 2018.

19- YAMADA S., FUKUHARA N., OYAMA K., TAKESHITA A. and TAKEUCHI Y.: Trans sphenoidal surgery for the treatment of remaining or recurring pituitary Tumors in acromegaly. Neurosurgery, 67: 949-956, 2010.

20- GOUDAKOS J.K., MARKOU K.D. and GEORGALAS C.: Endoscopic versus microscopic trans-sphenoidal pituitary surgery: A systematic review and meta-analysis. Clin. Otolaryngol., 36: 212-220, 2011.
21- JAIN A.K., GUPTA A.K., PATHAK A., BHANSALI A and BAPURAJ J.R.: Excision of pituitary adenomas: Randomized comparison of surgical modalities. Br. J. Neurosurg., 21: 328-31, 2007.

22- LITTLE A.S., KELLY D.F., WHITE W.L., GARDNER P.A., FERNANDEZ-MIRANDA J.C., CHICOINE M.R., BARKHOUDARIAN G., CHANDLER J.P., PREVEDELLO D.M., LIEBELT B.D., SFONDOURIS J., MAYBERG M.R., TRANSSPHER Study Group: Results of a prospective multicenter controlled study comparing surgical outcomes of microscopic versus fully endoscopic transsphenoidal surgery for nonfunctioning pituitary adenomas: The Transsphenoidal Extent of Resection (TRANSSPHER) Study. J. Neurosurg., 22: 1-11, 2019.

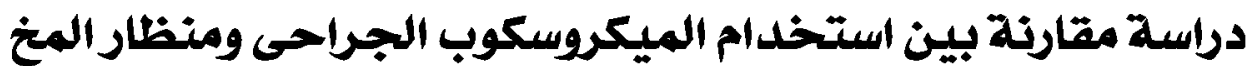 لإستئصال الورم المرتجع للغدة الميكوب النخامية}

الهدف من البحث: هوالمقارنة بين استخدام الميكروسكوب الجراحى والمنظار المخى لإستئصال الورم المرتجع للغدة النخامية وتحليل النتائج المترتبة عليه.

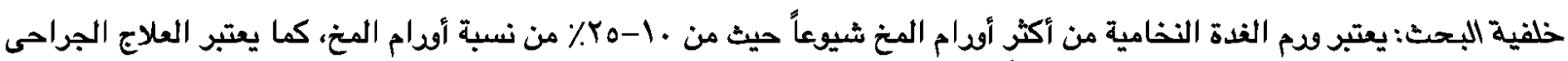

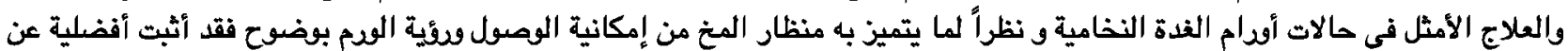

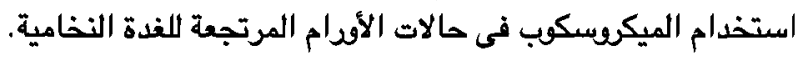

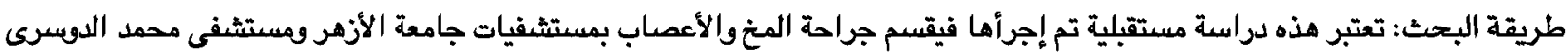

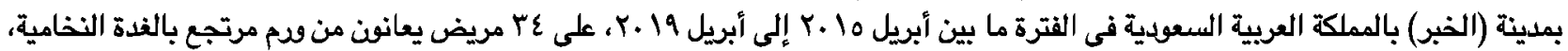

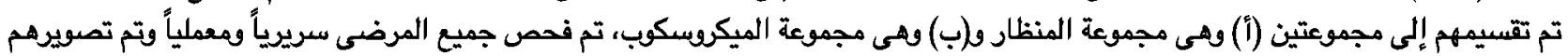

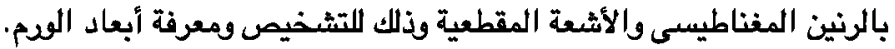

نتائج البحث: أثبت البحث أن إستئصال الأهدام المرتجعة للغدة النخامية هى جراحة فعالة وآمنة، كما وصت الدراسة بإستخدام منظار

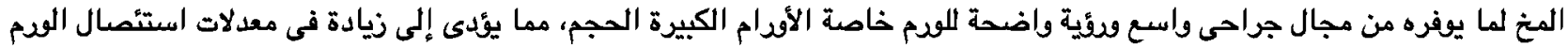

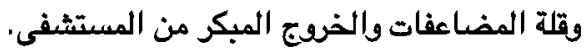

